\title{
STRUKTUR TEGAKAN DAN SEBARAN JENIS TERENTANG (Campnosperma auriculata) DAN MENDARAHAN (Knema laurina) DI HUTAN RAWA GAMBUT
}

\author{
Stand Structure and Distribution of Terentang (Campnosperma auriculata) and Mendarahan \\ (Knema laurina) in Peat Swamp Forest
}

Istomo $^{1^{*}}$ dan Abdul Aziz ${ }^{2}$

(Diterima Maret 2021/Disetujui April 2021)

\begin{abstract}
Peat swamp forests in Indonesia have an important role as a water provider, water storage, carbon storage, and as a place to live for flora and fauna. Terentang (Campnosperma auriculata) and mendarahan (Knema laurina) are some of the main trees in peat swamp ecosystem. This research aims to determaine stand structure and distribution of terentang and mendarahan species in peat swamp forests. The research was conducted at Sebangau National Park and Sungai Bram Itam Peatland Protected Forest using the vegetation analysis method with a plot size of $100 \mathrm{~m} \times 100 \mathrm{~m}$, divided into sub-plots size $20 \mathrm{~m} \times 20 \mathrm{~m}$, and used for data collection for trees with size $\geq 10 \mathrm{~cm}$. The results in Sebangau National Park was 115 individuals of terentang, 10 individuals of mendarahan and total of all species was 1043 individuals. while in the Sungai Bram Itam Peatland Protected Forest was 5 individuals of terentang, 21 individuals of mendarahan and total of all species was 543 individuals. The stand structure at both locations classified as normal. The spreading pattern of Terentang and mendarahan trees is a uniform distribution pattern.
\end{abstract}

Keywords: Campnosperma auriculata, Knema laurina, Peat swamp, Species distribution, Stand structure

\section{PENDAHULUAN}

Luas lahan gambut di Indonesia mencapai 21 juta ha yang menjadikan Indonesia sebagai negara dengan luas lahan gambut tropika yang terbesar di dunia. Lahan gambut memiliki peran yang sangat penting dalam menopang kehidupan sebagai habitat flora dan fauna, pengendali banjir serta pengendali perubahan iklim global. Sifat khusus yang dimiliki lahan gambut akan sulit pulih apabila ekosistemnya terganggu, dikarenakan proses pembentukan lahan gambut yang berlangsung selama ribuan tahun dalam pembusukan vegetasi. Perlindungan ekosistem lahan gambut sangat penting diterapkan dengan pengelolaan secara bijak serta memperhatikan keseimbangan ekologi, melalui pengelolaan yang terintegrasi (Wibowo 2009).

Dalam pengelolaan ekosistem gambut tentunya perlu mengetahui tentang struktur dan komposisi tumbuhan yang ada pada ekosistem gambut. Terentang dan mendarahan merupakan jenis pohon utama pada ekosistem gambut yang termasuk kedalam kelompok Kayu Komersil Dua (KKD). Jenis pohon Terentang (Camnosperma auriculatum) biasa ditemukan pada ketinggian berkisar 500-1000 mdpl dan memiliki tinggi mencapai $40 \mathrm{~m}$ serta diameter mencapai $90 \mathrm{~cm}$, dengan berat jenis kayunya berkisar 310-600 kg/m3 (rata-rata $435 \mathrm{~kg} / \mathrm{m} 3$ ) (Soerianegara dan Lemmens 1994). Jenis

\footnotetext{
${ }^{1}$ Dosen Departemen Silvikultur, Fakultas Kehutanan dan Lingkungan, IPB University

* Penulis korespondensi: e-mail: istomo19@gmail.com

2 Mahasiswa Departemen Silvikultur, Fakultas Kehutanan dan Lingkungan, IPB University
}

pohon Mendarahan (Knema laurina) biasa ditemukan di sumatera, jawa, dan Kalimantan. Spesies ini dapat memiliki tinggi mencapai $29 \mathrm{~m}$ dengan diameter $30 \mathrm{~cm}$. Jenis ini biasa dimanfaatkan menjadi Plywood, papan, rangka pintu \& jendela, peti, moulding.

Kajian mengenai struktur tegakan dan sebaran jenis pada hutan rawa gambut sangat diperlukan untuk memperoleh informasi dasar guna menunjang kegiatan pengelolaan yang lestari dan berkelanjutan. Baik dalam hal kelestarian jenis pada tegakan hutan yang dikelola, maupun kelestarian hasil dalam suatu pembinaan hutan. Penelitian ini bertujuan untuk mengetahui struktur tegakan dan sebaran jenis terentang dan mendarahan di hutan rawa gambut. Hasil penelitian ini diharapkan dapat memberikan informasi tentang struktur tegakan dan sebaran jenis terentang dan mendarahan di hutan rawa gambut.

\section{METODE PENELITIAN}

\section{Lokasi dan Waktu Penelitian}

Penelitian ini dengan menggunakan data dari proyek ITTO Puslitbang dan IPB yang dilaksanakan pada bulan Juni 2010. Lokasi pengambilan data sekunder didapatkan dari kawasan Taman Nasional Sebangau Kalimantan Tengah dan Hutan Lindung Gambut Sungai Bram Itam Kabupaten Tanjung Jabung Barat.

\section{Alat dan Bahan}

Data yang digunakan dalam penelitian ini berupa data sekunder Permanent Sampling Plot / PSP 3 Taman 
Nasional Sebangau Kalimantan Tengah dan seri PSP 7 Hutan Lindung Gambut Sungai Bram Itam. Alat yang digunakan dalam penelitian ini meliputi personal computer (PC) dengan software Ms. Excel untuk pengolahan data.

\section{Pengumpulan Data}

Data penilitian ini berupa data sekunder bersumber dari data tahun 2010 yang diambil oleh ITTO Puslitbang hutan dan IPB dengan membuat jalur berpetak. Data sekunder ini dilakukan pengolahan dilakukan pada tahun 2021. Pengambilan data lapang dilakukan berdasarkan keterwakilan komposisi dan penyebaran tumbuhan di hutan rawa gambut. Banyaknya petak contoh yang diambil sebanyak 1 petak pada ke dua lokasi dengan luas masing-masing 1 ha berbentuk bujur sangkar $(100 \mathrm{~m} \mathrm{x}$ $100 \mathrm{~m}$ ) dan dibagi ke dalam sub-sub petak berukuran $20 \mathrm{~m}$ $\mathrm{x} 20 \mathrm{~m}$.

Data yang dikumpulkan dalam kegiatan analisis vegetasi ini dengan kriteria diameter $\geq 10 \mathrm{~cm}$. Pada setiap petak diberi label: nomor PSP, nomor plot, Nomor pohon, berdiameter dan jenis pohon.

\section{Analisis Data}

\section{Indeks Nilai Penting (INP)}

Indeks nilai penting (INP) digunakan untuk menetapkan dominansi suatu jenis terhadap jenis lainnya. INP merupakan penjumlahan dari kerapatan relatif (KR), dominansi relatif (DR), dan frekuensi relatif (FR) untuk tingkat tiang dan tingkat pohon, serta penjumlahan KR dan FR untuk tingkat semai, tingkat pancang, tumbuhan bawah, semak, dan herba (Soerianegara dan Indrawan 2002):

Kerapatan $(\mathrm{K})=\frac{\text { Jumlah individu suatu jenis }(N)}{\text { Luas petak contoh }(\text { ha })}$

Kerapatan Relatif $(\mathrm{KR})=\frac{\text { Kerapatan suatu jenis }}{\text { Kerapatan seluruh Jenis }} \times 100 \%$

Frekuensi $(\mathrm{F})=\frac{\text { Jumlah plot ditemukan suatu jenis }}{\text { Jumlah seluruh plot }}$

Frekuensi Relatif $(\mathrm{FR})=\frac{\text { Frekuensi suatu jenis }}{\text { Frekuensi seluruh Jenis }} \times 100 \%$

Dominansi $(\mathrm{D})=\frac{\text { Jumlah bidang dasar suatu jenis }}{\text { Luas petak contoh }(\text { ha })}$

Dominansi Relatif $(\mathrm{DR})=\frac{\text { Dominansi suatu jenis }}{\text { Dominansi seluruh Jenis }} \times 100 \%$

INP $(\%)=\mathrm{KR}+\mathrm{FR}$ (untuk tingkat semai dan pancang)

$\mathrm{INP}(\%)=\mathrm{KR}+\mathrm{FR}+\mathrm{DR}$ (untuk tingkat tiang dan pohon)

\begin{tabular}{|c|c|c|c|c|}
\hline \multicolumn{5}{|c|}{$\stackrel{20 \mathrm{~m}}{\rightleftarrows}$} \\
\hline 1 & 2 & 3 & 4 & 5 \\
\hline 6 & 7 & 8 & 9 & 10 \\
\hline 11 & 12 & 13 & 14 & 15 \\
\hline 16 & 17 & 18 & 19 & 20 \\
\hline 21 & 22 & 23 & 24 & 25 \\
\hline
\end{tabular}

Gambar 1 Sketsa plot penelitian di tiap lokasi

\section{Indeks Dominansi Jenis $(\mathrm{C})$}

Indeks Dominansi jenis (C) merupakan perhitungan untuk mengetahui penguasaan suatu jenis pada suatu komunitas. Indeks dominansi dihitung menggunakan rumus Margalef (Indriyanto 2012) yaitu:

$C=\sum_{i=1}^{n}\left(\frac{n i}{N}\right)^{2}$

Keterangan:

$\mathrm{C}=$ Indeks Dominansi Jenis

ni $=$ Jumlah individu jenis ke-i

$\mathrm{N}=$ Total individu

\section{Indeks Keanekaragaman Jenis $\left(\mathbf{H}^{\prime}\right)$}

Analisis Indeks Keanekaragaman Jenis (H') dihitung menggunakan rumus keanekaragaman jenis Shannon Diversity Indeks (Magurran 1988):

$H^{\prime}=-\sum_{i=1}^{n}\left[\left(\frac{n i}{N}\right) \ln \left[\left(\frac{n i}{N}\right)\right]\right.$

Keterangan:

H' = Indeks Keanekaragaman Jenis Shannon

$\mathrm{Ni}=$ Jumlah individu jenis ke-i

$\mathrm{N}=$ Total individu seluruh jenis

\section{Indeks Kekayaan Jenis (R)}

Indeks Kekayaan jenis dihitung menggunakan rumus Margallef (Magurran 1988):

$R=\frac{(S-1)}{\ln (N)}$

Keterangan:

$\mathrm{R}=$ Indeks Kekayaan Jenis

$\mathrm{S}=$ Jumlah jenis yang ditemukan

$\mathrm{N}=$ Jumlah total individu

\section{Indeks Kemerataan Jenis (E)}

Indeks Kemerataan Jenis (E) menunjukkan tingkat kemerataan individu per jenis dalam suatu area. Nilai E dihitung menggunakan rumus (Magurran 1988):

$\mathrm{E}=\frac{H^{\prime}}{\ln (S)}$

Keterangan:

$\mathrm{E}=$ Indeks kemerataan jenis

$\mathrm{H}^{\prime}=$ Indeks keanekaragaman jenis

$\mathrm{Ln}=$ Logaritma natural

$\mathrm{S}=$ Jumlah spesies

\section{Indeks Penyebaran Jenis}

Pada umumnya jenis tumbuhan memiliki pola penyebaran yang berbeda. Morishita (1959) menyatakan bahwa untuk melihat pola penyebaran suatu jenis dihitung dengan rumus:

$$
\mathrm{I} \delta=\mathrm{q} \times \Sigma \frac{\mathrm{xi}(\mathrm{xi}-1)}{\mathrm{T}(\mathrm{T}-1)}
$$

Keterangan:

I $\delta=$ indeks Moroshita

$\mathrm{xi}=$ jumlah individu pada petak ke-I $(\mathrm{i}=1,2,3 \mathrm{dst})$

$\mathrm{q}=$ jumlah petak pengamatan

$\mathrm{T}=$ total jumlah individu seluruh petak

Jika:

$\mathrm{I} \delta=1$ maka pola penyebaran individu suatu jenis acak (random),

I $\delta<1$ maka pola penyebaran individu suatu jenis seragam (uniform),

I $\delta>1$, pola penyebaran individu suatu jenis mengelompok (clumped). 


\section{Biomassa Total}

Model pendugaan biomassa dipilih dari beberapa bentuk hubungan, yaitu model logaritma, ekponensial dan polynomial. Pemilihan model didasarkan pada bentuk sebaran data, bentuk umum pertumbuhan pohon dan besarnya nilai koefisien determinasi (R2) (Istomo 2002).

$\mathrm{W}=0,0145 \mathrm{D} 3-0,4659 \mathrm{D} 2+30,64 \mathrm{D}-263,32$ $\mathrm{R} 2=(96 \%)$

\section{HASIL DAN PEMBAHASAN}

\section{Komposisi dan Struktur}

Kerapatan dalam suatu tegakan menggambarkan komposisi dan struktur pada tegakan tersebut, karena memperlihatkan variasi jenis pohon dan kelas diameter. Menurut Husch et al. (2003) struktur tegakan dapat diuraikan sebagai variasi jenis pohon dan kelas umur yang tersusun oleh perbedaan lapisan vegetasi dan penyebaran kelas diameter. Pada tegakan normal kurva perbandingan kerapatan akan berbentuk huruf "J" terbalik. Hal tersebut menunjukkan bahwa semakin besar kelas diameter memiliki jumlah individu yang semakin sedikit dikarenakan persaingan antar individu dalam memenuhi kebutuhan unsur hara mineral tanah, air dan cahaya yang dapat menyebabkan terhambatnya pertumbuhan hingga matinya individu pohon (Meyer et al. 1961, Soerianegara dan Indrawan 2002).

Kondisi struktur tegakan dan komposisi jenis dapat dilihat berdasarkan kondisi kerapatan dalam suatu tegakan. Kerapatan jenis terentang, mendarahan dan jenis lain pada lokasi penelitian dapat dilihat pada Tabel 1. Pada lokasi PSP 3 didapatkan nilai kerapatan jenis terentang sebesar 115 individu/ha (11.03\%), mendarahan sebesar 10 individu/ha $(0.96 \%)$, dan jenis lain sebesar 918 individu/ha (88.02\%). Pada lokasi PSP 7 didapatkan nilai kerapatan jenis terentang sebesar 5 individu/ha $(0.92 \%)$, mendarahan sebesar 21 individu/ha $(3.87 \%)$, dan jenis lain sebesar 517 individu/ha (95.21\%).

Perbedaan jumlah individu jenis pada kelas diameter menggambarkan kondisi struktur tegakan. Jumlah

Tabel 1 Perbandingan kerapatan (K) Terentang dan Mendarahan dengan jenis lain

\begin{tabular}{lrrrr}
\hline \multirow{2}{*}{ Jenis } & \multicolumn{2}{c}{ Individu/ha } & \multicolumn{2}{c}{ Persentase (\%) } \\
\cline { 2 - 5 } & PSP 3 & PSP 7 & PSP 3 & \multicolumn{1}{c}{ PSP 7 } \\
\hline Terentang & 115 & 5 & $11.03 \%$ & $0.92 \%$ \\
Mendarahan & 10 & 21 & $0.96 \%$ & $3.87 \%$ \\
Jenis Lain & 918 & 517 & $88.02 \%$ & $95.21 \%$ \\
\hline Total & 1043 & 543 & $100.00 \%$ & $100.00 \%$ \\
\hline
\end{tabular}

Tabel 2 Jumlah pohon per kelas diameter di lokasi penelitian

\begin{tabular}{llrrrrrr}
\hline & & \multicolumn{6}{c}{ Kelas Diameter $(\mathrm{cm})$} \\
\cline { 3 - 8 } Lokasi & Jenis & $10-$ & $20-$ & $30-$ & $40-$ & $50-$ & \\
& & 19 & 29 & 39 & 49 & 59 & $\geq 60$ \\
\hline PSP 3 & Terentang & 78 & 31 & 6 & 0 & 0 & 0 \\
& Mendarahan & 9 & 1 & 0 & 0 & 0 & 0 \\
& Jenis Lain & 760 & 134 & 11 & 8 & 4 & 1 \\
PSP 7 & Terentang & 4 & 1 & 0 & 0 & 0 & 0 \\
& Mendarahan & 19 & 2 & 0 & 0 & 0 & 0 \\
& Jenis Lain & 388 & 111 & 15 & 2 & 1 & 0 \\
\hline
\end{tabular}

individu per kelas diameter pada lokasi penelitian dapat dilihat pada Tabel 2.

Pada PSP 3 individu terentang hanya ada pada rentang diameter diameter 10-39 $\mathrm{cm}$, sedangkan mendarahan hanya ada pada rentang diameter $10-29 \mathrm{~cm}$. Pada PSP 7 individu terentang dan mendarahan hanya ada pada rentang diameter 10-29 cm. Jika dibandingkan dengan individu jenis lain terlihat perbedaan yang cukup signifikan dimana individu pohonnya memiliki diameter mencapai $\geq 60 \mathrm{~cm}$ pada PSP 3 dan pada PSP 7 mencapai rentang diameter $10-59 \mathrm{~cm}$. Hal ini sangat mungkin terjadi mengingat perbedaan jumlah individu yang signifikan antara jenis terentang dan mendarahan dengan jenis lainnya seperti yang terlihat pada Tabel 1 .

Kondisi tegakan pada lokasi penelitian dapat dilihat berdasarkan kurva perbandingan antara kerapatan dan kelas diameter pada Gambar 2. Hal ini menunjukkan kurva yang berbentuk seperti huruf "J" terbalik, hal tersebut sesuai dengan pernyataan Meyer et al. (1961). Pada kurva tersebut menunjukkan pada kelas diameter $10-19 \mathrm{~cm}$ memiliki jumlah individu yang paling banyak, kondisi seperti ini mendukung kelestarian hutan karena stok permudaan tersebut sangat penting untuk memelihara kemampuan regenerasi hutan (Susanti 2014). Pertumbuhan yang terjadi mengakibatkan terjadinya proses seleksi alam. Secara alami, persaingan ini mengakibatkan terjadinya pengurangan jumlah individu yang bertahan hidup pada setiap tingkat kelas diameter (Kusmana dan Susanti 2015).

Indeks nilai penting (INP) menunjukkan jenis dominan dalam suatu tegakan. Semakin tinggi nilai INP suatu jenis pohon, semakin dominan jenis tersebut pada suatu tegakan. Menurut Murty dan Supriana (1986) semakin tinggi nilai INP suatu jenis menunjukkan semakin tingginya penguasaan pada komunitas jenis tersebut tumbuh. Jenis dominan dalam suatu komunitas menunjukkan bahwa jenis tersebut berhasil memanfaatkan sebagian besar sumber daya yang tersedia dalam persaingan dengan jenis lain. Perbandingan nilai INP Terentang, Mendarahan dan 3 jenis tertinggi pada lokasi penelitian dapat dilihat pada Tabel 3. Jika dibandingkan dengan 3 jenis lainnya, pada PSP 3 jenis terentang menempati INP tertinggi dengan nilai sebesar $30.19 \%$ dan mendarahan berada pada posisi terendah dengan nilai INP sebesar 3.64\%. Pada PSP 7 jenis terentang memiliki nilai INP terendah dengan nilai sebesar $3.26 \%$ dan mendarahan berada di posisi keempat dengan nilai INP sebesar $11.07 \%$.

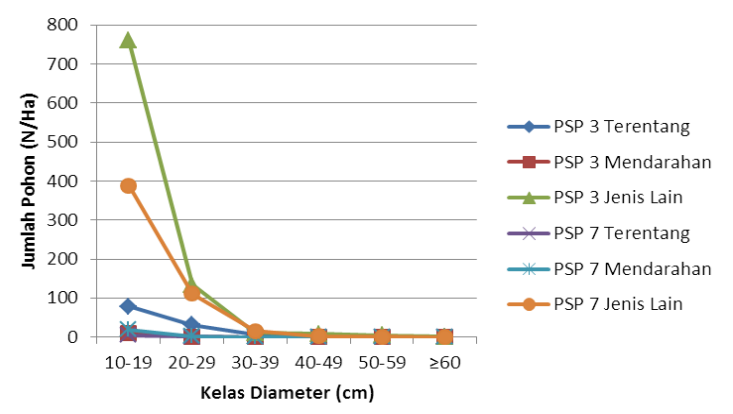

Gambar 2 Perbandingan kerapatan terentang, mendarahan dan jenis lain 
Kelestarian suatu tegakan dapat dilihat berdasarkan potensi dan pertumbuhan pohon di dalamnya yang dapat dihitung berdasarkan jumlah individu dan volume pada tiap kelas diameter. Jumlah individu dan volume jenis terentang, mendarahan, dan jenis lain berdasarkan kelas diameter (10 sampai $\geq 60)$ dapat dilihat pada Tabel 4 . Jenis terentang memiliki individu pada rentang 10-39 cm pada PSP 3 dan rentang $10-29 \mathrm{~cm}$ pada PSP 7. Sementara jenis mendarahan memiliki individu yang mencapai rentang 10-29 $\mathrm{cm}$ pada kedua lokasi. Hal tersebut menunjukkan bahwa potensi terentang pada PSP 3 lebih besar dibandingkan dengan mendarahan yang hanya mampu bersaing sampai rentang diameter $20-29 \mathrm{~cm}$. PSP 7 jenis terentang dan mendarahan memiliki potensi yang tidak jauh berbeda karena kedua jenis tersebut hanya mampu tumbuh sampai rentang diameter 20-29 cm, namun mendarahan memiliki potensi yang lebih besar dibandingkan dengan terentang dikarenakan jumlah individu yang ada dilokasi tersebut lebih banyak dengan memiliki 21 individu.

\section{Sebaran Jenis}

Sebaran jenis dalam suatu area diperlukan untuk mengetahui penyebaran individu yang berpengaruh dalam mengambil keputusan tentang metode apa yang akan digunakan untuk mengestimasi kepadatan atau

Tabel 4 Perbandingan indeks nilai penting (INP) Terentang, Mendarahan dan 3 jenis tertinggi

\begin{tabular}{llr}
\hline Lokasi & Jenis & INP $(\%)$ \\
\hline PSP 03 & Terentang & 30.19 \\
& Jambu-jambu & 27.23 \\
& Meranti & 24.16 \\
& Pasir-pasir & 22.35 \\
& Mendarahan & 3.64 \\
PSP 07 & Kayu hitam & 52.02 \\
& Kelat & 36.79 \\
& Punak & 22.06 \\
& Mendarahan & 11.07 \\
& Terentang & 3.26 \\
\hline
\end{tabular}

kelimpahan suatu populasi (Rani 2003). Sebaran jenis pada suatu tegakan mempengaruhi luas bidang dasar (LBDS) atau basal area (m2/ha) pada tegakan tersebut. Basal area jenis terentang, mendarahan, jenis lain dan seluruh jenis pada lokasi penelitian dapat dilihat pada Tabel 5.

PSP 3 memiliki basal area sebesar $25.22 \mathrm{~m} 2 /$ ha dan pada PSP 7 memiliki basal area sebesar $13.57 \mathrm{~m} 2 / \mathrm{ha}$, yang menunjukkan pada PSP 3 memiliki basal area lebih besar dikarenakan jumlah individu dalam tegakan tersebut lebih banyak dibandingkan dengan PSP 7. PSP 3 jika dibandingkan dengan basal area penelitian lain di Kalimantan, Sidiyasa (2012) pada Tuanan dan Katunjung sebesar 18,05 m2/ha, Mirmanto dalam Sidiyasa (2012) pada Sebangau 27,60 m2/ha, Mensemat 24,29 m2/ha, relatif tidak terlalu berbeda jauh dengan penelitian lain di sebangau dan mensemat dan lebih besar dari Tuanan dan Katunjung. PSP 7 jika dibandingkan dengan basal area penelitian lain di Sumatera, Samsoedin dan Heriyanto (2010) di Leuser 24,52 m2/ha, Bismark (2008) di Siberut $17,68 \mathrm{~m} 2 / \mathrm{ha}$, lebih kecil jika dibandingkan penelitian lain, hal ini diduga karena adanya perambahan di kawasan HLG Sungai Bram Itam oleh masyarakat.

Indeks dominansi menunjukkan penguasaan suatu jenis pada suatu tegakan. Menurut Wibowo (1999) bahwa semakin tinggi nilai indeks dominansi jenis

Tabel 5 Basal area terentang, mendarahan, jenis lain dan Seluruh Jenis

\begin{tabular}{lrrrr}
\hline & \multicolumn{2}{c}{ PSP 3 } & \multicolumn{2}{c}{ PSP 7 } \\
\cline { 2 - 5 } \multicolumn{1}{c}{ LBDS } & $\mathrm{m} 2 / \mathrm{ha}$ & \multicolumn{1}{c}{$\%$} & $\mathrm{~m} 2 / \mathrm{ha}$ & \multicolumn{1}{c}{$\%$} \\
\hline Terentang & 3.31 & $13.12 \%$ & 0.11 & $0.79 \%$ \\
Mendarahan & 0.17 & $0.66 \%$ & 0.35 & $2.56 \%$ \\
Jenis lain & 21.74 & $86.22 \%$ & 13.11 & $96.65 \%$ \\
Total & 25.22 & & 13.57 & \\
\hline
\end{tabular}

Tabel 6 Indeks dominansi (C) Terentang dan Mendarahan dengan jenis lain

\begin{tabular}{ll}
\hline \multicolumn{2}{c}{ Indeks Dominansi Jenis } \\
\hline PSP 3 & 0.068 \\
PSP 7 & 0.091 \\
\hline
\end{tabular}

Tabel 3 Kerapatan, potensi terentang dan mendarahan dengan jenis lain

\begin{tabular}{|c|c|c|c|c|c|c|c|c|}
\hline \multirow{2}{*}{ Lokasi } & \multirow{2}{*}{ Jenis } & \multirow{2}{*}{$\begin{array}{l}\text { Kerapatan } \\
\text { dan Volume }\end{array}$} & \multicolumn{6}{|c|}{ Kelas Diameter $(\mathrm{cm})$} \\
\hline & & & $10-19$ & $20-29$ & $30-39$ & $40-49$ & $50-59$ & $\geq 60$ \\
\hline \multirow[t]{10}{*}{ PSP 3} & \multirow[t]{2}{*}{ Mendarahan } & $\mathrm{N} / \mathrm{Ha}$ & 9.00 & 1.00 & - & - & - & - \\
\hline & & $\mathrm{V} / \mathrm{Ha}$ & 0.61 & 0.29 & - & - & - & - \\
\hline & \multirow[t]{2}{*}{ Terentang } & $\mathrm{N} / \mathrm{Ha}$ & 78.00 & 31.00 & 6.00 & - & - & - \\
\hline & & $\mathrm{V} / \mathrm{Ha}$ & 7.46 & 9.48 & 4.32 & - & - & - \\
\hline & \multirow[t]{2}{*}{ Jenis lain } & $\mathrm{N} / \mathrm{Ha}$ & 760.00 & 134.00 & 11.00 & 8.00 & 4.00 & 1.00 \\
\hline & & $\mathrm{V} / \mathrm{Ha}$ & 60.71 & 39.78 & 9.67 & 13.92 & 12.99 & 12.92 \\
\hline & Persentase & $\mathrm{N}(\%)$ & 1.07 & 0.61 & - & - & - & - \\
\hline & Mendarahan & $\mathrm{V}(\%)$ & 0.89 & 0.59 & - & - & - & - \\
\hline & Persentase & $\mathrm{N}(\%)$ & 10.14 & 22.96 & 54.55 & - & - & - \\
\hline & Terentang & $\mathrm{V}(\%)$ & 12.16 & 23.65 & 44.70 & - & - & - \\
\hline \multirow[t]{10}{*}{ PSP 7} & \multirow[t]{2}{*}{ Mendarahan } & $\mathrm{N} / \mathrm{Ha}$ & 19.00 & 2.00 & - & - & - & - \\
\hline & & $\mathrm{V} / \mathrm{Ha}$ & 1.28 & 0.49 & - & - & - & - \\
\hline & \multirow[t]{2}{*}{ Terentang } & $\mathrm{N} / \mathrm{Ha}$ & 4.00 & 1.00 & - & - & - & - \\
\hline & & $\mathrm{V} / \mathrm{Ha}$ & 0.41 & 0.22 & - & - & - & - \\
\hline & \multirow[t]{2}{*}{ Jenis lain } & $\mathrm{N} / \mathrm{Ha}$ & 388.00 & 111.00 & 15.00 & 2.00 & 1.00 & - \\
\hline & & $\mathrm{V} / \mathrm{Ha}$ & 33.82 & 32.22 & 12.34 & 2.87 & 2.94 & - \\
\hline & Persentase & $\mathrm{N}(\%)$ & 4.85 & 1.79 & - & - & - & - \\
\hline & Mendarahan & $\mathrm{V}(\%)$ & 3.73 & 1.52 & - & - & - & - \\
\hline & Persentase & $\mathrm{N}(\%)$ & 0.98 & 0.88 & - & - & - & - \\
\hline & Terentang & $\mathrm{V}(\%)$ & 1.16 & 0.66 & - & - & - & - \\
\hline
\end{tabular}


menunjukkan bahwa dominansi yang semakin dipusatkan pada beberapa jenis, sedangkan jika nilai indeks dominansi jenisnya semakin rendah, maka dominansi akan semakin menyebar pada lebih banyak jenis. Indeks dominansi pada lokasi penelitian dapat dilihat pada Tabel 6.

PSP 3 memiliki nilai C sebesar 0.068 , sedangkan PSP 7 memiliki nilai sebesar 0.091. Nilai indeks dominansi pada kedua lokasi didapatkan hampir mendekati 0 , hal ini menunjukkan bahwa tidak adanya pemusatan jenis tertentu pada komunitas (Purnama et al. 2019). Nilai C yang rendah umumnya ditemukan pada komunitas heterogen seperti hutan alam termasuk pada rawa gambut. Semakin rendah nilai $\mathrm{C}$ menggambarkan pola penguasaan jenis dalam komunitas tersebut relatif menyebar pada banyak jenis dan mempunyai peluang yang relatif seimbang dalam mempertahankan kelestarian jenis dan pertumbuhannya, karena sebagian besar jenis-jenis yang menempati komunitas tersebut mampu menyesuaikan dengan lingkungan (Mawazin dan Subiakto 2013).

Indeks keanekaragaman jenis menunjukkan tingkat variasi suatu jenis dalam suatu tegakan. Menurut Heddy (1994) Indeks keanekaragaman menunjukkan hubungan antara jumlah spesies dengan jumlah individu yang menyusun suatu komunitas. Sedangkan Desmukh (1992) menjelaskan bahwa keanekaragaman jenis lebih besar apabila equitabilitasnya lebih besar, yaitu jika keberadaan populasi-populasi tersebut antara satu sama lain dominansi jenisnya merata, bukan beberapa populasi sangat banyak sedangkan populasi lain sangat sedikit. Indeks keanekaragaman jenis pada kedua lokasi penelitian dapat dilihat pada Tabel 7.

PSP 3 memiliki nilai H' sebesar 2.955, sedangkan pada PSP 7 memiliki nilai H' sebesar 2.890. Hal ini

Tabel 6 Indeks Keanekaragaman Jenis $\left(\mathrm{H}^{\prime}\right)$ pada lokasi penelitian

\begin{tabular}{cc} 
lokasi penelitian \\
\hline Indeks keanekaragaman Jenis \\
\hline PSP 3 & 2.955 \\
PSP 7 & 2.890 \\
\hline
\end{tabular}

Tabel 7 Indeks kekayaan jenis (R) pada lokasi penelitian

\begin{tabular}{ll}
\hline \multicolumn{3}{c}{ Indeks Kekayaan Jenis } \\
\hline PSP 3 & 5.180 \\
PSP 7 & 6.511 \\
\hline
\end{tabular}

Tabel 8 Indeks kemerataan jenis (E) pada lokasi penelitian

\begin{tabular}{cc}
\hline \multicolumn{2}{c}{ Indeks Kemerataan Jenis } \\
\hline PSP 3 & 0.818 \\
PSP 7 & 0.773 \\
\hline
\end{tabular}

Table 9 Indeks Morishita (I $\delta$ ) Terentang dan Mendarahan di lokasi penelitian

\begin{tabular}{lcc}
\hline \multirow{2}{*}{ Jenis } & \multicolumn{2}{c}{ Indeks Morishita } \\
\cline { 2 - 3 } & PSP 3 & PSP 7 \\
\hline Terentang & 1.52 & 2.30 \\
Mendarahan & 1.11 & 1.42 \\
\hline
\end{tabular}

menunjukkan bahwa pada kedua lokasi penelitian memiliki tingkat keanekaragaman sedang. Odum (1996) menyebutkan bahwa suatu komunitas memiliki nilai $1 \leq$ $\mathrm{H}^{\prime} \leq 3$ menunjukkan tingkat keanekaragaman sedang. Semakin tinggi nilai H' menggambarkan semakin tinggi tingkat kestabilannya. Lokasi penelitian memiliki tingkat kestabilan jenis yang sangat stabil, menurut Kent dan Paddy dalam Mazawin dan Subiakto A (2013) suatu komunitas jika memiliki nilai $\mathrm{H}^{\prime}>2$ dikatakan komunitas sangat stabil.

Indeks kekayaan jenis suatu tegakan ditentukan berdasarkan perbandingan temuan jenis dengan jumlah individu yang ditemukan. Indeks kekayaan jenis pada lokasi penelitian dapat dilihat pada Tabel 8 .

PSP 3 memiliki nilai R sebesar 5.180 sedangkan pada PSP 7 memiliki nilai R sebesar 6.511. Kedua lokasi memiliki nilai indeks kekayaan jenis > 5, hal ini menunjukkan bahwa kedua lokasi memiliki kekayaan jenis yang tinggi. Magurran (1988) menjelaskan bahwa nilai kekayaan jenis tinggi memiliki nilai $\mathrm{R}>5$.

Indeks Kemerataan Jenis menunjukkan tingkat kemerataan individu per jenis dalam suatu area. Nilai indeks kemerataan jenis pada lokasi penelitian dapat dilihat pada Tabel 9. PSP 3 memiliki nilai E sebesar 0.818 dan pada PSP 7 memiliki nilai E sebesar 0.773, hal tersebut menunjukkan bahwa kemeretaan individu pada lokasi penelitian tergolong tinggi. menurut Magurran (1988) besaran nilai $\mathrm{E}>0,6$ menunjukkan nilai kemerataan jenis tergolong tinggi. Hal ini mengindikasikan bahwa kelestarian jenis pada komunitas tersebut cenderung dapat dipertahankan (Mawazin dan Subiakto 2013).

Tiap jenis pohon umumnya mempunyai pola penyebaran yang berbeda dan dapat dihitung dengan menggunakan indeks morishita. Nilai indeks morishita terentang dan mendarahan pada lokasi penelitian dapat dilihat pada Tabel 10. PSP 3 jenis terentang memiliki nilai sebesar 1.52 dan mendarahan memiliki nilai sebesar 1.11. Pada PSP 7 jenis terentang memiliki nilai sebesar 2.30 dan mendarahan memiliki nilai sebesar 1.42. Kedua jenis pada lokasi penelitian memiliki nilai indeks morishita >1, hal ini menunjukkan bahwa pola penyebaran pohon pada jenis terentang dan mendarahan memiliki pola penyebaran yang mengelompok. Menurut Soegianto dalam Istomo dan Afnani M (2014) menyatakan bahwa pola penyebaran organisme di alam jarang ditemukan memiliki pola yang seragam, tetapi pada umumnya mempunyai pola penyebaran mengelompok.

TPTI merupakan salah satu sistem silvikultur untuk mengatur atau menata suatu tegakan. Sutisna (2001) menjelaskan TPTI adalah kegiatan yang dilakukan pada tegakan tidak seumur untuk memacu pertumbuhan tegakan sesuai keadaan hutan agar tegakan tertata secara optimal dan lestari. Sistem TPTI merupakan sistem yang paling sedikit mengubah ekosistem hutan dengan menyingkirkan pohon-pohon tua agar pohon yang lebih muda dapat tumbuh produktif. Jumlah pohon inti dan yang dapat ditebang pada lokasi penelitian dapat dilihat pada Tabel 11 dan 12 . 
Tabel 11 menggambarkan pohon inti dan pohon yang boleh ditebang berdasarkan sistem TPTI tahun 1989 dimana pohon inti memiliki rentang diameter antara 10$39 \mathrm{~cm}$ dan pohon yang boleh ditebang memiliki pohon yang boleh ditebang memiliki diameter $>40 \mathrm{~cm}$. PSP 3 pohon jenis terentang dan mendarahan tidak memiliki pohon yang boleh ditebang sedangkan jenis lain memiliki 14 pohon yang boleh ditebang. PSP 7 sama seperti pada PSP 3 untuk jenis terentang dan mendarahan tidak memiliki pohon yang boleh ditebang sedangkan untuk jenis lain memiliki 3 pohon yang boleh ditebang. Pohon inti dan pohon yang boleh ditebang berdasarkan sistem TPTI tahun 2009 dimana pohon inti memiliki rentang diameter antar 10-29 cm dan pohon yang boleh ditebang memiliki diameter $>30 \mathrm{~cm}$ ditunjukan pada Tabel 11 . PSP 3 pohon jenis terentang memiliki 6 pohon yang boleh ditebang dan mendarahan tidak memiliki pohon yang boleh ditebang sedangkan untuk jenis lain memiliki 24 pohon yang boleh ditebang. PSP 7 pohon jenis terentang dan mendarahan tidak memiliki pohon yang boleh ditebang sedangkan untuk pohon jenis lain memiliki 18 pohon yang boleh ditebang.

\section{Pendugaan Biomassa}

Tabel 10 Jumlah pohon inti dan pohon yang boleh ditebang berdasarkan sistem TPTI tahun 1989

\begin{tabular}{llcc}
\hline \multirow{2}{*}{ Lokasi } & \multicolumn{1}{c}{ Jenis } & Pohon inti & Pohon ditebang \\
\cline { 3 - 4 } & & $10-39 \mathrm{~cm}$ & $>40 \mathrm{~cm}$ \\
\hline PSP 3 & Terentang & 115 & 0 \\
& Mendarahan & 10 & 0 \\
& Jenis Lain & 904 & 14 \\
PSP 7 & Terentang & 5 & 0 \\
& Mendarahan & 21 & 0 \\
& Jenis Lain & 514 & 3 \\
\hline
\end{tabular}

Tabel 11 Jumlah pohon inti dan pohon yang boleh ditebang berdasarkan sistem TPTI tahun 2009

\begin{tabular}{llcc}
\hline \multirow{2}{*}{ Lokasi } & \multicolumn{1}{c}{ Jenis } & Pohon inti & Pohon ditebang \\
\cline { 3 - 4 } & & $10-29 \mathrm{~cm}$ & $>30 \mathrm{~cm}$ \\
\hline \multirow{2}{*}{ PSP 3 } & Terentang & 109 & 6 \\
& Mendarahan & 10 & 0 \\
& Jenis Lain & 894 & 24 \\
PSP 7 & Terentang & 5 & 0 \\
& Mendarahan & 21 & 0 \\
& Jenis Lain & 499 & 18 \\
\hline
\end{tabular}

Biomassa merupakan jumlah total bahan organik hidup pada suatu pohon yang dinyatakan dengan satuan ton berat kering tanur per satuan luas (Brown 1997, Sutaryo 2009). Tiap individu pohon memiliki biomassa yang berbeda-beda, sesuai dengan pertumbuhan pohon. Menurut Istomo (2002), peningkatan biomassa pohon seiring dengan peningkatan ketebalan gambut yang mampu dijangkau oleh perakaran dalam menyerap mineral tanah untuk memperbesar biomassa. Dekomposisi yang terjadi memberikan input karbon dan nutrisi dalam tanah untuk peningkatan produksi biomassa (Aerts \& Chapin 2000).

Pendugaan biomassa total jenis terentang, mendarahan dan jenis lain pada lokasi penelitian dapat dilihat pada Tabel 13 dan 14. Tabel 13 menunjukkan bahwa pada PSP 3 pohon jenis terentang memiliki biomassa total sebesar 27.94 ton, untuk jenis mendarahan memiliki biomassa total sebesar 1.21 ton, dan untuk jenis lain memiliki biomassa total sebesar 178.68 ton. Nilai biomassa total pada PSP 3 sebesar 207.84 ton. Tabel 14 menunjukkan bahwa pada PSP 3 pohon jenis terentang memiliki biomassa total sebesar 0.85 ton, untuk jenis mendarahan memiliki biomassa total sebesar 2.51 ton, untuk jenis lain memiliki biomassa total sebesar 107.83 ton. Nilai biomassa total pada PSP 7 sebesar 111.20 ton. Jika dibandingkan pada kedua lokasi penelitian pada PSP 7 memiliki pendugaan biomassa yang lebih sedikit, hal ini dikarenakan perbedaan kerapatan yang diduga akibat dari perambahan yang dilakukan oleh masyarakat sekitar kawasan hutan.

Kedua lokasi menunjukkan bahwa kelas diameter yang lebih rendah memiliki biomassa yang lebih besar dikarenakan kerapatan yang lebih besar. Menurut Widyasari et al. (2010) besarnya nilai kerapatan dapat memberikan kontribusi yang sangat besar terhadap potensi karbon terikat yang berhubungan erat dengan besarnya biomassa suatu pohon. Meskipun begitu, jika dibandingkan secara individu pada pohon yang memiliki kelas diameter yang lebih besar memiliki biomassa yang cukup besar. Hal ini dikarenakan kandungan biomassa terbesar pada pohon terdapat pada bagian batang pohon yang berarti semakin besar nilai dbh semakin mempercepat peningkatan biomasssanya (Widyasari et al. 2010, Siarudin dan Indrajaya 2014).

Persentase pendugaan biomassa pada lokasi penelitian dapat dilihat pada Tabel 15, Tabel 16 dan

Tabel 12 Pendugaan Biomassa total (ton) pada tiap kelas diameter di PSP 3

\begin{tabular}{lrrrrrrr}
\hline \multirow{2}{*}{ Jenis } & \multicolumn{7}{c}{ Biomassa (ton) per kelas diameter } \\
\cline { 2 - 8 } & $\mathbf{1 0 - 1 9}$ & $\mathbf{2 0 - 2 9}$ & $\mathbf{3 0 - 3 9}$ & $\mathbf{4 0 - 4 9}$ & $\mathbf{5 0 - 5 9}$ & $\mathbf{\geq 6 0}$ & $\geq \mathbf{1 0} \mathbf{~ c m}$ \\
\hline Terentang & 11.27 & 12.23 & 4.44 & 0.00 & 0.00 & 0.00 & 27.94 \\
Mendarahan & 0.84 & 0.36 & 0.00 & 0.00 & 0.00 & 0.00 & 1.21 \\
Jenis Lain & 87.98 & 51.26 & 9.29 & 11.57 & 9.70 & 8.85 & 178.68 \\
Total & 100.10 & 63.86 & 13.74 & 11.57 & 9.70 & 8.85 & 207.84 \\
\hline
\end{tabular}

Tabel 13 Pendugaan Biomassa total (ton) pada tiap kelas diameter di PSP 7

\begin{tabular}{lrrrrrrr}
\hline \multirow{2}{*}{ Jenis } & \multicolumn{1}{c}{ Biomassa (ton) per kelas diameter } \\
\cline { 2 - 8 } & $\mathbf{1 0 - 1 9}$ & $\mathbf{2 0 - 2 9}$ & $\mathbf{3 0 - 3 9}$ & $\mathbf{4 0 - 4 9}$ & $\mathbf{5 0 - 5 9}$ & $\mathbf{\geq 6 0}$ & $\geq \mathbf{1 0} \mathbf{~ c m}$ \\
\hline Terentang & 0.55 & 0.30 & 0.00 & 0.00 & 0.00 & 0.00 & 0.85 \\
Mendarahan & 1.81 & 0.70 & 0.00 & 0.00 & 0.00 & 0.00 & 2.51 \\
Jenis Lain & 49.54 & 41.61 & 12.04 & 2.42 & 2.21 & 0.00 & 107.83 \\
Total & 51.91 & 42.62 & 12.04 & 2.42 & 2.21 & 0.00 & 111.20 \\
\hline
\end{tabular}


Gambar 3. Pada gambar 3 menggambarkan perbandingan persentase pendugaan biomassa terentang, mendarahan dan jenis lain pada PSP 3 dan PSP 7. Pendugaan biomassa pohon jenis terentang pada PSP 3 memiliki nilai sebesar 27.94 ton (13.45\%) dan pada PSP 7 memiliki nilai sebesar 0.85 ton $(0.77 \%)$. Jenis mendarahan pada PSP 3 memiliki nilai sebesar 1.21 ton $(0.58 \%)$ dan pada PSP 7 memiliki nilai sebesar 2.51 ton $(2.26 \%)$

\section{SIMPULAN DAN SARAN}

\section{SIMPULAN}

Struktur tegakan pada kedua lokasi yakni PSP 3 Taman Nasional Sebangau dan PSP 7 Hutan Lindung Gambut Sungai Bram Itam memiliki struktur tegakan yang normal yang menunjukkan bahwa regenerasi pohon pada kedua tegakan tetap terjaga. PSP 3 ditemukan 37

Tabel 14 Persentase pendugaan biomassa total (ton) pada PSP 3

\begin{tabular}{lrr}
\hline \multicolumn{1}{c}{ Jenis } & $\begin{array}{c}\text { Biomassa (ton) } \\
\geq 10 \mathrm{~cm}\end{array}$ & $\%$ Persentase \\
\hline Terentang & 27.94 & $13.45 \%$ \\
Mendarahan & 1.21 & $0.58 \%$ \\
Jenis Lain & 178.68 & $85.97 \%$ \\
Total & 207.84 & $100.00 \%$ \\
\hline
\end{tabular}

Tabel 15 Persentase pendugaan biomassa total (ton) pada PSP 7

\begin{tabular}{lrr}
\hline \multicolumn{1}{c}{ Jenis } & $\begin{array}{c}\text { Biomassa (ton) } \\
\geq 10 \mathrm{~cm}\end{array}$ & $\%$ Persentase \\
\hline Terentang & 0.85 & $0.77 \%$ \\
Mendarahan & 2.51 & $2.26 \%$ \\
Jenis Lain & 107.83 & $96.97 \%$ \\
Total & 111.20 & $100.00 \%$ \\
\hline
\end{tabular}
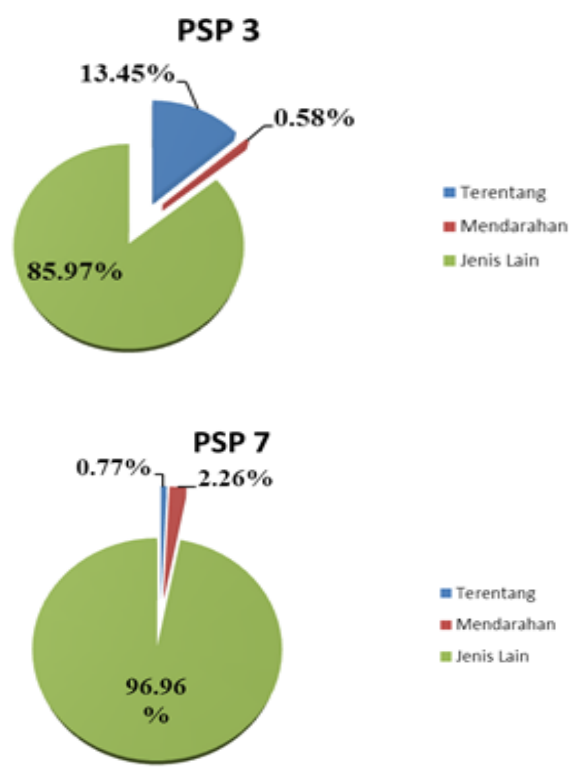

Gambar 3 Perbandingan pendugaan biomassa terentang, mendarahan dan jenis lain pada lokasi penelitian jenis pohon dengan jumlah individu pohon mencapai 1043 individu. Jenis pohon yang ditemukan diantaranya adalah terentang dan mendarahan. Jenis terentang memiliki nilai kerapatan sebesar 115 individu/ha sedangkan jenis mendarahan memiliki kerapatan sebesar 10 individu/ha. PSP 7 ditemukan 42 jenis pohon dengan jumlah individu pohon sebanyak 543 individu. Jenis pohon yang ditemukan diantaranya adalah terentang dan mendarahan. Jenis terentang memiliki nilai kerapatan sebesar 5 individu/ha sedangkan jenis mendarahan memiliki nilai kerapatan sebesar 21 individu/ha. Jenis pohon terentang dan mendarahan pada kedua lokasi memiliki pola penyebaran yang mengelompok.

\section{SARAN}

Perlunya pemantauan lanjutan secara berkala mengenai tegakan di rawa gambut pada kedua lokasi penelitian agar kondisi tegakan tetap terjaga dan dapat mempertahankan struktur tegakan normal pada kedua lokasi.

\section{DAFTAR PUSTAKA}

Aerts R, Chapin FS. 2000. The mineral nutrition of wild plants revisited: A re-evaluation of processes and patterns. Adv Ecol Res 30:1-67.

Bismark M, Heriyanto NM, Iskandar S. 2008. Biomasa dan kandungan karbon pada hutan produksi di cagar biosfer pulau Siberut, Sumatera Barat. Jurnal penelitian Hutan dan Konservasi Alam. 5(5): 397-407

Brown S. 1997. Estimating Biomass and Biomass Change of Tropical Forest.APrimer. FAO, USA. FAO Forestry Paper No 134.

Desmukh I. 1992. Ekologi dan Biologi Tropika. Jakarta (ID): Yayasan Obor Indonesia.

Heddy S. 1994. Prinsip-Prinsip Dasar Ekologi. Jakarta (ID): PT Raja Grafindo Persada

Husch B, Thomas WB, John AK. 2003. Forest Mensuration. 4th edition. New Jersey: John Wiley \& Sons, Inc.

Indriyanto. 2012. Ekologi Hutan. Jakarta (ID): PT Bumi Aksara.

Istomo. 2002. Kandungan fosfor dan kalium serta penyebarannya pada tanah dan tumbuhan hutan rawa gambut: studi kasus di wilayah Bagian Kesatuan Pemangkuan Hutan Bagan, Kabupaten Rokan Hilir, Riau [disertasi]. Bogor: Program Pascasarjana, Institut Pertanian Bogor.

Istomo dan Afnani M. 2014. Potensi dan sebaran jenis meranti (Shorea spp.) Pada kawasan lindung PT. Wana hijau pesaguan, Kalimantan Barat. Jurnal Silvikultur Tropika. 5(3): 196-205

Kusmana C, dan Susanti S. 2015. Komposisi dan struktur tegakan hutan alam di hutan pendidikan Gunung Walat, Sukabumi. Jurnal Silvikultur Tropika. 5(3): 210-217.

Magurran AE. 1988. Ecological Diversity and Its Measurement. London (UK): Croom Helm Ltd.

Mawazin dan Subiakto A. 2013. Keanekaragaman dan komposisi jenis permudaan alam hutan rawa 
gambut bekas tebangan di riau. Indonesian Forest Rehabilitation Jounal. 1(1): 59-73

Meyer HA, Recnagel B, Stevenson DD, Bartoo. 1961. Forest Management. New York(US): The Ronald Press Company.

Morisita M. 1959. Measuring of the dispersion of individuals and analysis of the distributional patterns. Biology. 2(4):215-233.

Murti RS, Supriana N. 1986. Evaluasi pelaksanaan system TPI. Buletin Penelitian kehutanan. vol 2.

Odum EP. 1996. Dasar-dasar Ekologi. Yogyakarta (ID): Gadjah Mada University Press.

Purnama A, Wasis B, dan Hilwan I. 2019. Karakteristik vegetasi di hutan alam dataran rendah, hutan tanaman, dan lahan pasca tambang nikel di Kabupaten Bombana. Jurnal Silvikultur Tropika. 10(3): 140-145.

Rani C. 2003. Metode pengukuran dan analisis pola spasial (dispersi) organisme bentik. Jurnal Protein 19:1351-1368.

Samsoedin I dan Heriyanto NM. 2010. Struktur dan komposisi hutan pamah bekas tebangan illegal di kelompok Hutan Sei Lepan, Sei Serdang, Taman Nasional Gunung Leuser Sumatera Utara. Jurnal penelitian Hutan dan Konservasi Alam. 7(3): 299314

Siarudin M dan Indrajaya Y. 2014. Persamaan allometrik jabon (Neolamarckia Cadamba Miq) untuk pendugaan biomassa di atas tanah pada hutan rakyat Kecamatan Pakenjeng Kabupaten Garut. Jurnal Penelitian Hutan Tanaman. 11(1): 1-9

Sidayasa K. 2012. Karakteristik hutan rawa gambut di Tuanan dan Katunjung, Kalimantan Tengah. Jurnal Penelitian Hutan dan Konservasi Alam. 9(2): 125-137
Soerianegara I, Lemmens RHMJ. 1994. Plant Resources of South East Asia. Timber Trees: Major commercial timbers. 5(1): 102-108.

Soerianegara I, Indrawan A. 2002. Ekologi Hutan Indonesia. Bogor (ID): Fakultas Kehutanan Institut Pertanian Bogor.

Susanti S. 2014. Komposisi jenis dan struktur tegakan regenerasi alami di Hutan Pendidikan Gunung walat, Sukabumi [Skripsi]. Bogor (ID): Institut Pertanian Bogor.

Sutaryo D. 2009. Penghitungan Biomassa: Sebuah Pengantar untuk Studi Karbon dan Perdagangan Karbon. Bogor (ID): Wetlands International Indonesia Programme.

Sutisna M. 2001. Silvikultur Hutan Alami di Indonesia. Jakarta (ID): Direktorat Jenderal Pendidikan Tinggi

Wibowo SH. 1999. Dinamika masyarakat tumbuhan di hutan rawa gambut bekas tebangan (Studi kasus di areal HPH PT. Kurnia Musi Plywood Industrial, Sumatera Selatan). [skripsi]. Bogor (ID): Fakultas Kehutanan Institut Pertanian Bogor.

Wibowo A. 2009. Peran Lahan Gambut dalam Perubahan Iklim Global. Bogor (ID): Pusat Penelitian dan Pengembangan Hutan Tanaman Kampus Balitbang Kehutanan

Widyasari NAE, Saharjo BH, Solichin, dan Istomo. 2010. Pendugaan biomassa dan potensi karbon terikat di atas permukaan tanah pada hutan rawa gambut bekas terbakar di Sumatera Selatan. Jurnal Ilmu Pertanian Indonesia. 15(1): 41-49. 